\title{
Sperm cells in the reproductive tract of the mare: Where can we find them?
}

\author{
Sandra M. Fiala', Luis A. Cruz', Rosangela F. Rodrigues' ${ }^{1}$, Maria Inês Jobim², Ricardo M. Gregory² and Rodrigo C. Mattos ${ }^{2}$ \\ Instituto de Biologia, Universidade de Pelotas' and Faculdade de Veterinária, Universidade do Rio Grande do Sul² (Brazil)
}

\section{Spermien im Reproduktionstrakt der Stute: Wo sind sie zu finden?}

Ziel der Studie war es, die Anwesenheit von Spermatozoen im Ovidukt und im Uterus zu überprüfen. 117 Stuten wurden inseminiert und nach $0.5 \mathrm{~h}(\mathrm{n}=16), 1 \mathrm{~h}(\mathrm{n}=26), 2 \mathrm{~h}(\mathrm{n}=40), 4 \mathrm{~h}(\mathrm{n}=21), 10 \mathrm{~h}(\mathrm{n}=7)$ oder $24 \mathrm{~h}(\mathrm{n}=7)$ geschlachtet. Die Geschlechtsorgane wurden entnommen und gespült bzw. für die histologische und rasterelektronmikroskopische Untersuchung aufgearbeitet. Insgesamt wurden bei $76 \%$ der Stuten wurden Samenzellen in den Eileiterspülproben beobachtet. Die Spermien konnten eine halbe Stunde nach Insemination in den Eileiterspülproben nachgewiesen werden. Es bestand kein Unterschied zwischen der Anzahl der Spermien in den Eileiterspülproben und in der Anzahl der Stuten, bei denen Spermien im Ovidukt beobachtet werden konnten. Lichtmikroskopisch wurden bei 62\% der Stuten Spermien nachgewiesen. Mit Zunahme des Zeitintervalls zur Insemination nahm der Anteil der Stuten mit Spermatozoen ab. Spermatozoen lieBen sich bei 14 (70\%) der Stuten in der uterotubalen Verbindung (UTJ) beobachten, ebenfalls mit einer Abnahme bezogen auf die seit der Insemination verflossenen Zeit. Rasterelektronenmikroskopisch lag der Anteil der sich im Ovidukt befindlichen Spermien bei 33,3\%. Zwischen den zu den dominanten Follikeln ipsi- und contralateralen Eileitern und Uterushörnern bestand kein Unterschied. Zusammenfassend wird festgestellt, dass Samenzellen nach einer halben Stunde im Ovidukt nachweisbar sind und dort für mindestens 24 Stunden verbleiben. Die Uterindrüsen können hierbei als Reservoir dienen. Die Anzahl der Stuten mit Spermien auf dem luminalen Epithel in den Uterindrüsen sowie der uterotubalen Verbindung nimmt mit dem zeitlichen Abstand zur Insemination ab.

Schlüsselwörter: Reproduktion, Spermien, Ovidukt, Uterus, Besamung

\section{Summary}

The objective of this study was to verify the presence of spermatozoa in the oviducts and uterus. One hundred seventeen mares in estrus were inseminated and slaughtered $0.5 \mathrm{~h}(\mathrm{n}=16), 1 \mathrm{~h}(\mathrm{n}=26), 2 \mathrm{~h}(\mathrm{n}=40)$ or $4 \mathrm{~h}(\mathrm{n}=21), 10 \mathrm{~h}(\mathrm{n}=7)$ or $24 \mathrm{~h}(\mathrm{n}=7)$ after Al. Reproductive tracts were recovered and flushed or processed for histological examination or SEM. In total in $76 \%$ of the mares sperm cells were observed in flushes from oviducts. At $0.5 \mathrm{~h}$ after insemination sperm cells were detected in oviductal flushes. No differences were observed in the number of sperm cells, that were observed in the oviductal flushes and the number of mares that had sperm cells in the oviducts. By light microscopy, sperm cells were observed in $62.6 \%$ of the mares, and the number of mares with spermatozoa diminished as time from Al increased. Spermatozoa in the uterotubal junctions (UTJ) were observed in 14 (70\%) of the mares and there was a decreased in the number of mares with sperm cells observed in the UTJ in relation to the time of Al. In the oviducts processed for SEM, spermatozoa were observed in 33.3\%. There was no difference between the number of sperm observed in the oviduct and uterine horns ipsilateral and contralateral to the dominant follicle. It was concluded that sperm cells can be observed 30 min after insemination and remain in the oviducts for at least $24 \mathrm{~h}$. Uterine glands can act as a sperm reservoir. The number of mares with sperm cells on the lumenal epithelium, glands and in the UTJ diminished as the time from Al increased.

Keywords: Reproduction, spermatozoa, oviduct, uterus, insemination

\section{Introduction}

During mating or artificial insemination semen are deposited directly into the uterus. Uterine contractions after insemination carry sperm back and forth between uterine body and horn tips. Mann et al. (1956) found seminal components in the mare oviduct within $1 \mathrm{~h}$ after copulation and spermatozoa have been found in the oviducts of mares $2 \mathrm{~h}$ after $\mathrm{Al}$, increasing until $4 \mathrm{~h}$ after, with a reduction at $6 \mathrm{~h}$ (Bader 1982). Also, when mares are flushed at 0.5 or $2 \mathrm{~h}$ after insemination, conception rates are lowered, but uterine lavage has no adverse effect on fertility if performed at $4 \mathrm{~h}$ after insemination (Brinsko et al. 1990, Brinsko et al. 1991). The objective of this study was to verify the presence of spermatozoa in the oviducts and uterus by means of flushings, histology or scanning electron microscopy (SEM) preparations.

\section{Material and methods}

One hundred seventeen mixed-breed mares in estrus were selected from a population of horses sent to slaughter in an abattoir. Semen was collected from a fertile stallion. Mares with a dominant follicle $>35 \mathrm{~mm}$ in diameter and no bacterial growth or neutrophils in uterine smears were inseminated with a total dose of $500 \times 10^{6}$ cooled sperm $\left(25 \times 10^{6} \mathrm{ml}\right.$ 1 spermatozoa diluted in skim milk) stored at 18-22 hours before use. Mares were slaughtered $0.5 \mathrm{~h}(\mathrm{n}=16), 1 \mathrm{~h}$ $(n=26), 2 h(n=40)$ or $4 h(n=21), 10 h(n=7)$ or $24 h(n=$ 7) after $\mathrm{Al}$; reproductive tracts were recovered within 10 minutes. Oviducts with the uterotubal junctions (UTJ) were separated from the uterus, placed in a dish and flushed with phosphate-buffered saline (PBS) from the infundibulum toward the isthmus. The flush was stirred and a sample of 
Table 1 Percentage of mares presenting sperm cells in the oviducts and mean and standard deviation of sperm cells flushed from the oviducts and UTJ different times after Al

Prozentualer Anteil der Stuten mit nachweisbaren Spermien im Eileiter, Mittelwert und Standardabweichung der Samenzellen in den Spülproben aus dem Eileter und der uterotubalen Verbindung zu verschiedenen Zeiten nach der Insemination.

\begin{tabular}{cccc}
\hline Time after Al & Number of mares & \% of mares with sperm & Mean ( \pm SD) numbers [ log ${ }_{10}(y+10)$ ] \\
\hline $0.5 \mathrm{~h}$ & 3 & 66.6 & $3.05 \pm 1.82$ \\
$1 \mathrm{~h}$ & 10 & 80 & $3.69 \pm 1.46$ \\
$2 \mathrm{~h}$ & 20 & 90 & $2.19 \pm 1.64$ \\
$4 \mathrm{~h}$ & 10 & 71.4 & $1.12 \pm 0.06 \pm 0.06$ \\
\hline
\end{tabular}

Table 2 Number and percentage of mares presenting sperm cells in the uterine epithelium, uterine glands and UTJ in light microscopy Anzahl und Prozentsatz der Stuten mit lichtmikroskopisch nachweisbaren Spermien auf dem luminalen Epithel, in den Uterindrüsen und der uterotubalen Verbindung.

\begin{tabular}{cccc}
\hline Time afterAl & Uterine epithelium & Uterine glands & UTJ \\
\hline $1 \mathrm{~h}$ & $8(80 \%)$ & $7(70 \%)$ & $5(83.3 \%)$ \\
$2 \mathrm{~h}$ & $10(76.9 \%)$ & $8(61.5 \%)$ & $7(70 \%)$ \\
$4 \mathrm{~h}$ & $4(50 \%)$ & $5(62.5 \%)$ & $2(50 \%)$
\end{tabular}

each tubal flushing was placed in a Neubaver chamber. Each sperm counted in the chamber represented 5 sperms $/ \mathrm{mm}^{3}$. The uterus was sectioned and a portion from uterine body, each horn and each UTJ was obtained after macroscopic examination. The samples were fixed in Bouin's solution and processed for histological examination. The slides were stained with hematoxylin-eosin and analyzed under a light microscope (400x). Spermatozoa adjacent to the luminal epithe-

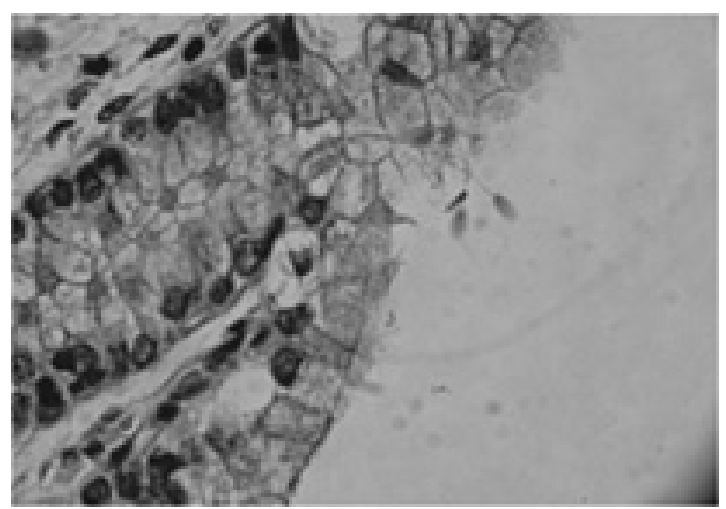

Fig 1 Sperm cells in the uterine lumen Spermien im Uteruslumen

lium and within the uterine glands and UTJ were searched. In six mares, slaughtered two hours after insemination, the oviducts were completely separated from uterus and perfused by an artery with glutaraldehyde $2.5 \%$, post fixed with $\mathrm{Os} \bigcirc 4$ and processed for SEM.

To normalize the data, the number of sperm cells in flushes was transformed to $\log 10(y+10)$. Data were analyzed using ANOVA. Numbers of spermatozoa in the flushes of the oviducts were considered as dependent variables and time befo- re artificial insemination as independent variable. The Tukey's test was used to compare the means. Pearson linear correlation was used in the statistical analysis. The number of mares with and without sperm cells in the oviducts was evaluated by Chi-Square analysis. Values were considered to be statistically significant at $\mathrm{P}<0.05$.

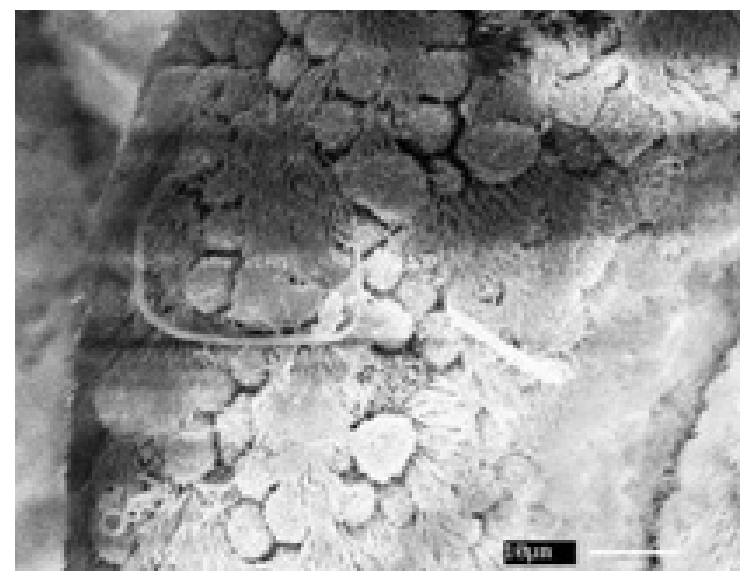

Fig 2 Spermatozoa in the mare's oviduct processed for SEM Rasterelektronenmikroskopische Abbildung von Spermien

\section{Results and discussion}

Sperm cells were observed in flushes from oviducts in $76 \%$ of the mares regardless the insemination moment. Spermatozoa were detected in oviductal flushes at $0.5 \mathrm{~h}$ after insemination. Differences between groups were observed neither in the number of sperm cells $(P=0.27)$ flushed nor in the number of mares with sperm cells in the oviducts $(P=0.26)$ (Table 1). Sperm cells were observed by light microscopy in $62.6 \%$ of the mares in the uterine epithelium and glands (Figure 1). A 
Table 3 The number and percentage of ipsi and contralateral uterine horns and oviducts to the dominant follicle presenting sperm cells Anzahl und prozentuale Häufigkeit der nachweisbaren Spermien in den zum dominanten Follikel ipsi- und kontralateralen Eileiter und Uterushorn

\begin{tabular}{lccc}
\hline & \multicolumn{2}{c}{ Ipsilateral } & Contralateral \\
\cline { 2 - 4 } & $\mathrm{n}$ & $\%$ & $\mathrm{n}$ \\
Uterine horns - light microscopy & 23 & 79.3 & 18 \\
Oviducts- Flushing & 14 & 11 & 40.7 \\
\hline
\end{tabular}

significant $(P<0.02)$ negative correlation between the time from $\mathrm{Al}$ and the number of mares presenting spermatozoa in the uterine lumen $(r=-0.955)$ and glands $(r=-0.914)$ was observed (Table 2). The number of mares with sperm cells in the uterine epithelium and in the glands decreased $(P<$ 0.01) $4 \mathrm{~h}$ after Al. This may be due to the elimination and the decrease in the supply of new sperm cells.

In twenty mares inseminated, 1, 2 or 4 hours after insemination, the utero-tubal junction was collected and was analyzed to search for spermatozoa using a light microscope. Spermatozoa in the UTJ were observed in $14(70 \%)$ of the mares. As observed in the uterus, there was a decreased in the number of mares with sperm cells observed in the UTJ in relation to the time of $\mathrm{Al}$ (Table 2).

In six oviducts processed for SEM, from mares inseminated two hours before slaughter, spermatozoa were observed in 33.3\% (Figure 2).

There was no difference between the number of sperm observed in the oviduct and uterine horns ipsilateral and contralateral to the dominant follicle, the sperm distribution is identical independently to the site of the dominant follicle (Table 3).

It was concluded that sperm cells can be observed $30 \mathrm{~min}$ after insemination and remain in the oviducts for at least 24. Sperm glands can act as a sperm reservoir. The number of mares with sperm cells in uterine epithelium, glands and in the UTJ diminished as the time from Al increased. The sperm distribution is identical in the uterine horns and in the oviducts independently to the site of the dominant follicle.

\section{References}

Bader H. (1982) An investigation of sperm migration into the oviducts of the mare. J. Reprod. Fertil. Suppl. 32, 59-64

Brinsko S. P, Varner D. D., Blanchard T. L. and Meyers S. A. (1990) The effect of post-breeding uterine lavage on pregnancy rate in mares. Theriogenol. 33, 465-475

Brinsko S. P., Varner D. D. and Blanchard T. L. (1991) The effect of uterine lavage performed four hours post insemination on pregnancy rates in mares. Theriogenol. 35, $1111-1119$

Mann T., Polge C. and Rowson L. E. A. (1956) Participation of seminal plasma during the passage of spermatozoa in the female reproductive tract of the pig and horse. J. Endocr. 13, 133-140

Sandra M. Fiala

Reprolab

Departamento de Medicina Animal

FAVET-UFRGS

Av. Bento Goncalves 9090

91540-000 Porto Alegre-RS

Brazil

smfiala@ufrgs.br 